\title{
越田俊也 学位論文審查要旨
}

$\begin{array}{ccccc}\text { 主查 } & \text { 重 } & \text { 政 } & \text { 秋 } \\ \text { 副主查 } & \text { 難 } & \text { 波 } & \text { 栄 } \\ \text { 同 } & \text { 久 } & \text { 留 } & \text { 一 } & \text { 郎 }\end{array}$

\section{主論文}

Stabilizing effects of eicosapentaenoic acid on Kv1. 5 channel protein expressed in mammalian cells

（ほ乳類培養細胞株における不飽和脂肪酸エイコサペンタエン酸のKv1.5チャネル蛋白安 定化作用に関する研究）

（著者: 越田俊也、倉田康孝、野津智美、廣田裕、Ting Y Kuang、Peili Li、Udin Bahrudin、 原田真吾、三明淳一朗、山本康孝、星川淑子、井川修、檜垣克美、相馬雅明、 吉田明雄、二宮治明、汐田剛史、白吉安昭、久留一郎)

平成21年 European Journal of Pharmacology 掲載予定 
学 位 論 文 要 旨

Stabilizing effect of eicosapentaenoic acid on Kv1.5 channel protein expressed in mammalian cells

\section{（ほ乳類培養細胞における不飽和脂肪酸エイコサペンタエン酸のKv1.5チャネル蛋白安定 化作用に関する研究)}

n-3多価不飽和脂肪酸（EPA及びDHA）の抗不整脈作用は心筋イオンチャネルの修飾で説明 される。電位依存性Kチャネルファミリーに属するKv1.5チャネルは心筇細胞の $\mathrm{I}_{\mathrm{Kur}}$ 電流を形 成して活動電位再分極に重要な役割を演じる。EPA及びDHAの慢性投与はKv1.5チャネルの生 合成や細胞内輸送に影響する可能性が示唆されているが、それらのチャネル蛋白の安定性 への影響は知られていない。本研究ではEPA及びDHAの急性および慢性投与がKv1.5チャネル 蛋白の発現と活性に及ぼす効果を検討した。

\section{方 法}

培養COS7 細胞にKv1.5-FLAGを遺伝子導入後、細胞を回収し、ウエスタンブロット法によ りKv1.5-FLAG蛋白を検出した。また、Kv1.5蛋白の分解速度を測定するため、遺伝子導入し た細胞をサイクロフォスファミドで処理し、各時間ごとに回収した細胞についてウエスタ ンブロット法によりそのシグナルを検出し蛋白半減期を測定した。また、免疫蛍光抗体染 色によりKv1.5-FLAG、ER-EYFP、Golgi-EYFP、AcGFP-Mem、Endosome-EGFPの細胞内局在を観 察した。Kv1.5-FLAGまたは mock vectorおよびgreen fluorescent protein（GFP）を遺伝 子導入し、パッチクランプ法により全膜電流を記録し、発現したKv1.5チャネル電流を測 定した。さらに心臓でのKv1.5の発現はラットにEPAを摂取させて評価した。

\section{結 果}

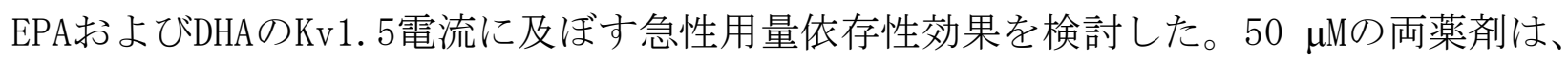
脱分極パルス中 $(0 \mathrm{mV} \sim 60 \mathrm{mV})$ に電流減衰を伴ってKv1.5電流のピーク值を有意に抑制し た。次にEPAとDHAのKv1.5チャネルの発現と活性におよぼす慢性用量依存性効果を検討した。 $10 \mu \mathrm{M}$ のPAの慢性投与は有意にKv1.5-FLAG蛋白を増加させたが、100 $\mu \mathrm{M}$ のEPAはそれを有 意に減少させた。一方で、DHAは10 100 $\mu \mathrm{M}$ の範囲で用量依存性にKv1. 5-FLAG蛋白を減少 
させた。 0.1 ～10 $\mu \mathrm{M}$ 範囲での両薬剤の慢性効果の検討では、EPAは用量依存性に Kv1.5-FLAG蛋白を有意に増加させたが、一方、同じ濃度のDHAはKv1.5-FLAG蛋白量の変化を 起こさなかった。ラットにEPAを内服させることで心房筋細胞の内因性Kv1.5蛋白は有意に 増加した。さらに1 $\mu \mathrm{M}$ の EPAを12時間作用させると細胞に発現させたKv1.5電流は脱分極パ ルス0 mV〜60 mVの領域で有意に増加した。次にKv1.5チャネル蛋白の安定性ならびに細胞 内局在におよぼすEPAの慢性効果を検討した。コントロールではKv1.5-FLAG蛋白の半減期は

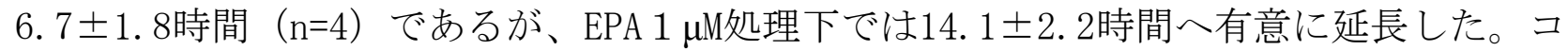
ントロールでのKv1.5-FLAG蛋白のCOS7細胞内局在を比較した。Kv1.5-FLAG蛋白はER-EYFP およびGolgi-EYFPと共局在することから小胞体およびGolgi体に存在する。一方 Endosome-EGFPとは共局在しないことに加えてリソソーム阻害薬であるクロロキン（2 $\mu \mathrm{M} ）$ がKv1.5-FLAG蛋白の安定性に影響をおよぼさないことからKv1.5-FLAG蛋白はエンドゾーム には局在しない。1 $\mu \mathrm{M}$ のPA慢性投与下では小胞体とゴルジ体でのKv1.5-FLAG蛋白が著明 に蓄積した。またコントロールではKv1.5-FLAG蛋白は細胞表面マーカーであるAcGFP-Mem とは共局在しないが、1 $\mu \mathrm{M} の \mathrm{EPA}$ 存在下ではAcGFP-Memに共局在する。細胞分画法を用いた 検討でも10 $\mu \mathrm{M}$ のEPAの投与は有意に小胞体および細胞膜でのKv1. 5-FLAG蛋白の局在を増加

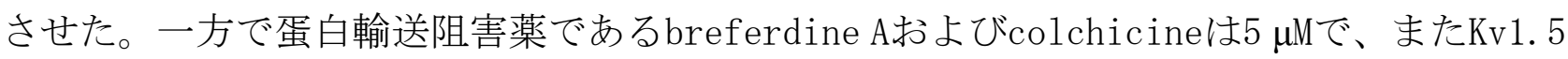
電流阻害薬4-aminopyridine（4-AP）は1 mM で12時間処置するとEPAによるKv1.5電流の増加 作用が消失した。

\section{考 察}

本研究では低用量のEPAの慢性投与がKv1.5チャネル蛋白を増加させることが判明した。 低用量EPAのKv1.5チャネル蛋白増加の作用機序は、小胞体とゴルジ体でEPAがKv1.5チャネ ル蛋白の4-AP結合部位に結合し、蛋白構造の変化を介して蛋白の安定を促進することであ り、細胞膜での発現の増加はその二次的作用であると考えられる。Kv1.5チャネル蛋白の 脂肪酸アシル化の違いがEPAとDHAの作用の違いを説明し得るが今後の検討が必要である。 心房筋はKv1.5チャネル蛋白を多く発現しているが、慢性心房細動や後天的心疾患の一部 ではそれが減少している。低用量EPAの投与がこれらの病態に影響する可能性がある。

\section{結 語}

低用量EPAは慢性効果としてKv1.5チャネル蛋白を安定化しKv1.5電流を増加させること が明らかとなった。 